\title{
Rebuilding after collapse: evidence for long-term cohort dynamics in the native Hawaiian rain forest
}

Post-print/Accepted manuscript

Hans Juergen Boehmer

Helene H. Wagner

James D. Jacobi

Grant C. Gerrish

Dieter Mueller-Dombois

Boehmer, H. J., Wagner, H. H., Jacobi, J. D., Gerrish, G. C. and Mueller-Dombois, D. (2013), Rebuilding after collapse: evidence for long-term cohort dynamics in the native Hawaiian rain forest. J Veg Sci, 24: 639-650. doi:10.1111/jvs.12000

This is the peer reviewed version of the following article: Boehmer, H. J., Wagner, H. H., Jacobi, J. D., Gerrish, G. C. and Mueller-Dombois, D. (2013), Rebuilding after collapse: evidence for long-term cohort dynamics in the native Hawaiian rain forest. J Veg Sci, 24: 639-650, which has been published in final form at $\underline{\text { doi:10.1111/jvs. } 12000}$ This article may be used for non-commercial purposes in accordance with Wiley Terms and Conditions for Self-Archiving.

\section{HOW TO CITE TSPACE ITEMS}

Always cite the published version, so the author(s) will receive recognition through services that track citation counts, e.g. Scopus. If you need to cite the page number of the TSpace version (original manuscript or accepted manuscript) because you cannot access the published version, then cite the TSpace version in addition to the published version using the permanent URI (handle) found on the record page. 
REBUILDING AFTER COLLAPSE: EVIDENCE FOR LONG-TERM COHORT

DYNAMICS IN THE NATIVE HAWAIIAN RAIN FOREST

4 Hans Juergen Boehmer, Helene H. Wagner, James D. Jacobi, Grant C. Gerrish \& Dieter

5 Mueller-Dombois

7 Boehmer, H.J. (corresponding author, hj.boehmer@uni-bonn.de): University of Bonn,

8 Interdisciplinary Latin America Center (ILZ), Walter-Flex-Str. 3, 53113 Bonn, Germany;

9 and: Technical University of Munich, Department of Ecology and Ecosystem

10 Management, Chair for Strategic Landscape Planning and Management, Emil-Ramann-

11 Strasse 6, 85350 Freising-Weihenstephan, Germany

12 Wagner, H.H. (helene.wagner@utoronto.ca): University of Toronto, Department of

13 Ecology and Evolutionary Biology, 3359 Mississauga Road, Mississauga, Ontario L5L

14 1C6, Canada

15 Jacobi, J.D. (jjacobi@usgs.gov): U.S. Geological Survey, Pacific Island Ecosystems

16 Research Center, 677 Ala Moana Blvd., Suite 615, Honolulu, HI 96813

17 Gerrish, G.C. (grant@hawaii.edu): University of Hawaii at Hilo, Department of

18 Biology, 200 W. Kawili St., Hilo, HI 96720, U.S.A.

19 Mueller-Dombois, D. (amdhawaii@aol.com): University of Hawaii at Manoa,

20 Department of Botany, 3190 Maile Way, Honolulu, HI 96822, U.S.A.

22 Running head: Rebuilding after collapse 


\section{Abstract}

Questions. Do long-term observations in permanent plots confirm the conceptual model of Metrosideros polymorpha cohort dynamics as postulated in 1987? Do

26 regeneration patterns occur independently of substrate age, i.e. of direct volcanic

27 disturbance impact?

28 Location. The windward mountain slopes of the younger Mauna Loa and the

29 older Mauna Kea volcanoes (island of Hawaii, U.S.A.).

Methods. After widespread forest decline (dieback), permanent plots were

31 established in 1976 in 13 dieback and 13 non-dieback patches to monitor the population

32 structure of M. polymorpha at approximately 5-year intervals. Within each plot of 20 x 20

$33 \mathrm{~m}$, all trees with $\mathrm{DBH}>2.5 \mathrm{~cm}$ were individually tagged, measured, and tree vigor

34 assessed; regeneration was quantified in 16 systematically placed subplots of $3 \times 5 \mathrm{~m}$.

35 Data collected in the subplots included the total number of $M$. polymorpha seedlings and

36 saplings ( 5 stem height classes). Here we analyze monitoring data from 6 time steps from

$37 \quad 1976-2003$ using repeated measures ANOVA to test specific predictions derived from

38 the 1987 conceptual model.

39 Results. Regeneration was significantly different between dieback and non-

40 dieback plots. In dieback plots, the collapse in the 1970s was followed by a 'sapling

41 wave' that by 2003 led to new cohort stands of M. polymorpha. In non-dieback stands,

42 seedling emergence did not result in sapling waves over the same period. Instead a

43 'sapling gap' (i.e. very few or no M. polymorpha saplings) prevailed as typical for mature

44 stands. Canopy dieback in 1976, degree of recovery by 2003, and the number of living

45 trees in 2003 were unrelated to substrate age. 
46 Conclusions. Population development of $M$. polymorpha supports the cohort

47 dynamics model, which predicts rebuilding of the forest with the same canopy species

48 after dieback. The lack of association with substrate age suggests that the long-term

49 maintenance of cohort structure in M. polymorpha does not depend on volcanic

50 disturbance but may be related to other environmental mechanisms, such as climatic

51 anomalies.

52

53 Keywords

54 canopy dieback; climatic anomalies; cohort senescence; cyclic succession; forest decline;

55 Metrosideros polymorpha; mono-dominant rain forest; montane rain forest; permanent

56 plots; stand demography; volcanic disturbance

58 Abbreviations

$59 \mathrm{DBH}=$ Diameter at Breast Height

$60 \quad$ DI $=$ Dieback Index

61

62

63 


\section{Introduction}

Canopy dieback has been reported from many forest ecosystems around the world

66 (Holloway 1977; Pickard 1983; Jane \& Green 1983; Wardle \& Allen 1983; Stewart \&

67 Veblen 1983; White 1986; Lawesson 1988; Ogden 1988; Kohyama 1988; Stewart 1989;

68 Auclair 1993; Enright 1993; Ogden et al. 1993; Ciesla \& Donaubauer 1994). The term

69 'dieback' has been defined as "progressive dying back from the tips of twigs, branches or

70 tops" (Podger 1981; Manion 1981, Ciesla \& Donaubauer 1994). In recent years, the

71 potential connection between dieback phenomena and climate change has sparked new

72 interest and scientific debate (Allen 2009; Allen et al. 2010; Aynekulu et al. 2011;

73 Boehmer 2011; Lewis et al. 2011).

On the island of Hawaii, about 50,000 ha of rainforest experienced a decline of

Metrosideros polymorpha trees between 1954 and the mid-1980s ('ohia dieback';

Burgan \& Nelson 1972, Petteys et al. 1975, Mueller-Dombois et al. 1980, Jacobi 1983,

77 Hodges et al. 1986, Mueller-Dombois 1993). Endemic M. polymorpha (Myrtaceae; o'hi'a

78 lehu'a) is the dominant canopy tree species in Hawaii's native montane rainforests

79 (Mueller-Dombois \& Fosberg 1998, Wagner et al. 1999). The forests affected were

80 located on the east-facing, windward side of the volcanic mountains Mauna Loa (4168 m)

81 and Mauna Kea (4205 m) between 700 and 1500 m elevation (Jacobi 1983; see Fig. 1). In

82 the late 1980s, the rapid expansion came to a halt (Jacobi et al. 1988).

83 The early hypothesis (Burgan \& Nelson 1972) that the Hawaiian rain forest

84 decline was caused by a virulent pathogen or a combination of biotic disease and pest

85 agents was ruled out after a decade of intensive disease research (Klijunas \& Ko

86 1973,1974; Papp et al. 1979; Hodges et al. 1986). Dieback stands were found on a variety

87 of volcanic substrates ranging in age from ca. 300 to $>140 \mathrm{~K}$ years (Mueller-Dombois 
2006). Dieback patterns were significantly related to the physical environment,

89 particularly the slope gradient, shape of terrain, the relative position on hill slope, annual

90 rainfall, and the type of substrate (Akashi \& Mueller-Dombois 1995). Thus, an alternative

91 hypothesis proposed that "dieback is initiated by a climatic instability [i.e. climatic

92 anomaly] which becomes effective through the soil moisture regime under certain

93 conditions of forest stand maturity" (Mueller-Dombois 1980:159).

94 This hypothesis gave rise to the 'cohort senescence theory' (Mueller-Dombois

95 1987). M. polymorpha populations are considered to have, in many cases, a uniform age

96 and stand structure ('cohorts'; Vogl 1969; Atkinson 1970), broadly comparable to tree

97 plantations or the natural disturbance-induced cohort stands of forests in other ecozones

98 (Boehmer \& Richter 1997). According to the theory, the uniform age and stand structure,

99 primarily induced by large-scale disturbances through volcanic eruptions, results in the

100 simultaneous ageing and finally death of the tree cohort ('cohort senescence'). Old cohorts

101 of canopy trees are considered predisposed to die due to their low potential for recovery

102 from stress (Mueller-Dombois 1987). In senescent stands, climatic anomalies such as

103 extreme rainfall events or prolonged drought may generate a physiological shock and

104 trigger dieback symptoms (Mueller-Dombois 1987, Gerrish et al. 1988, Gerrish 1990,

105 Auclair 1993). However, identification of cohorts by determination of tree age and stand

106 turnover rates, or the direct relation of growth and climatic events using dendroecological

107 methods is difficult since $M$. polymorpha does not form annual growth rings (Gerrish \&

108 Mueller-Dombois 1999). Therefore, the postulated cohort dynamics can best be evaluated

109 from long-term observational data.

$110 \quad$ Field data collected from 1976 to 1985 showed high numbers of seedlings and

111 small saplings of M. polymorpha in dieback plots, which was interpreted by Mueller- 
112 Dombois (1987) and Jacobi et al. (1988) as indication of a new cohort of M. polymorpha

113 trees. The term 'sapling wave' describes the expected movement of a peak in seedling

114 emergence through various sapling size classes into the tree layer. A conceptual

115 population dynamics model was presented, which predicted a full regeneration of the $M$.

116 polymorpha tree layer following dieback (Mueller-Dombois 1987, Jacobi 1993; Fig. 2).

117 However, this prediction was in stark contrast to the general belief that the remaining

118 rainforest "will be virtually eliminated in 15-25 years" (Petteys et al. 1975).

119 This model has not yet been tested with empirical data. We used a long-term data

120 set from permanent plots established in 1976 as a unique research opportunity to compare

121 the population dynamics of $M$. polymorpha between dieback and non-dieback plots over

12227 years. Specifically we assess whether dieback led to new cohorts within the $M$.

123 polymorpha population, and whether the forming of new cohorts occurred independently

124 of substrate age, according to the hypothesis that cohort dynamics is a recurring

125 phenomenon during the course of succession (Mueller-Dombois 1986). We developed the

126 following specific predictions from the conceptual cohort dynamics model proposed by

127 Mueller-Dombois in 1987 (see Fig. 2): (H1) the proportion of dead or dying canopy trees

128 (dieback index, DI) remains low and constant in time for non-dieback plots, while for

129 dieback plots, it decreases over time to the level of non-dieback plots; (H2) dieback plots

130 have higher densities of seedlings, saplings, and young trees than non-dieback plots; (H3)

131 a sapling wave occurs in dieback plots, but not in non-dieback plots; (H4) the shape of

132 the DBH distribution is skewed more to the left than in non-dieback plots following

133 disturbance and shifts back over time. In addition, we tested the association of tree vigor

134 and M. polymorpha population dynamics with substrate age. 


\section{Sampling design and data collection}

138 Study sites are located on the windward (east) side of the island of Hawaii (Fig. 3)

139 between the Wailuku River area (north) and the Kilauea area (south) on a variety of

140 volcanic substrates ranging from ca. 300 to 13,500 years B.P. The mean annual rainfall in

141 this area varies (S-N) from ca. $2500 \mathrm{~mm}$ to $7000 \mathrm{~mm}$ (Juvik \& Juvik 1998). Twenty-six

142 permanent plots $(20 \times 20 \mathrm{~m})$ were established in 1976 between ca. 900 and $1500 \mathrm{~m}$ of

143 elevation throughout the study area. In a stratified sampling design, 13 dieback and 13

144 non-dieback forest stands were selected so as to represent the total variation in forest

145 patterns identified from aerial photographs from 1972. An initial survey of the stands was

146 taken in 1976, and stands were reassessed using the same protocol (see below) in 1982,

$1471985,1990,1995$, and 2003. Due to its location in inaccessible terrain, one plot could not

148 be relocated after 1985 and was dropped from the data set.

149 Within each plot of $20 \times 20 \mathrm{~m}$, every tree of at least $5 \mathrm{~m}$ height was individually

150 tagged, DBH measured (in cm; 1976 and 2003 only), and tree vigor quantified on a scale

151 of 1-5, using the following classes: 1) fully foliated crowns; 2) some defoliated branches,

$15210-50 \%$ of the crown dead; 3 ) most upper crown branches defoliated, but with some

153 foliated adventitious branches along the trunk; 4) recently dead trees with small branches

154 and most of the bark remaining; 5) dead trees ("snags"), only major branches remaining,

155 most of the trunk without bark.

156 M. polymorpha regeneration was quantified in sixteen $3 \times 5 \mathrm{~m}$ subplots per plot,

157 systematically placed within each $20 \times 20 \mathrm{~m}$ plot (Jacobi 1983). Data collected in the

158 subplots include the total number of $M$. polymorpha seedlings (0.1-0.5 $\mathrm{m}$ tall) and the 
159 total number of $M$. polymorpha saplings in five stem height classes $(>0.5-1 \mathrm{~m},>1-2 \mathrm{~m}$, $160>2-3 \mathrm{~m},>3-4 \mathrm{~m},>4-5 \mathrm{~m})$.

161 We determined substrate age for each plot by referring to the Digital Data Base of

162 the Geologic Map of the Island of Hawai'i (Trusdell et al. 2006). For each lava flow or

163 tephra layer, we determined the median of all radiocarbon datings available from the data

164 base. For each plot, we identified the lava flow or tephra layer on which it was situated by

165 overlaying the GPS coordinates with the geological map in ArcGIS. Substrate age in

1661976 was defined as age BP +26 years, as BP refers to 1950 . Based on information from

167 the field, we reassigned plot 29 to an adjacent older tephra layer. No dating was available

168 for the substrate of plot 42.

\section{Data analysis}

171 Dieback index (DI) was defined as the proportion of dead or dying canopy trees

172 (vigor classes 3 - 5) per plot. Plots with DI larger than 50\% in 2003 were considered

173 outliers and classified as 'late dieback' plots (non-dieback in 1976, n=2) or 'no-

174 recovery' plots (dieback plots in 1976, $\mathrm{n}=3$ ). Thus, late dieback and no-recovery plots

175 did not conform with $\mathrm{H} 1$ and will be discussed separately. Further quantitative analysis

176 was restricted to the remaining 10 dieback and 10 non-dieback plots. For the calculation

177 of mean DI of dieback plots, missing values for Plot 13 for years 1982 - 1995 were

178 interpolated linearly between DI values for years 1976 and 2003.

179 To compare regeneration between dieback and non-dieback plots (H2), and to test

180 for the occurrence of a sapling wave (H3), we used repeated measures ANOVA to assess

181 the effects of dieback category, size class, and year on the number of seedlings, saplings, 182 and young trees. Abundances were $\log$-transformed with $\mathrm{y}^{\prime}=\log (\mathrm{y}+1)$ so as to stabilize 
183 the variance based on residual analysis. In the presence of a significant interaction, we

184 used Bonferroni-type multiple comparisons to assess for which years (6 comparisons) or

185 size classes (7 comparisons) there was a significant difference between dieback and non-

186 dieback plots, accounting for the nature (within- or between subject) and the total number

187 of comparisons $(k=13)$ (Howell 2010).

188 To test for change in stand structure $(\mathrm{H} 4)$ in terms of the mean number of living

189 trees (vigor classes $1-3$ ) between observation periods, a repeated measures ANOVA

190 was used to assess the effect of dieback category and year on the density of living trees

191 per hectare (square-root transformed). The same ANOVA was repeated for the mean

192 number of vigorous trees (vigor class 1). Temporal trend within each dieback category

193 was tested in the manner of a polynomial contrast, performing a $2^{\text {nd }}$ order polynomial

194 regression of density of living trees against the year (standardized). If both linear and

195 quadratic terms are significant, this indicates a general increase or decrease that levels off

196 after some time, whereas a linear effect only indicates continuing linear trend, a quadratic

197 effect only an increase followed by decrease or vice versa. In the presence of a significant

198 interaction, we used Bonferroni-type pairwise comparisons to assess for which years

199 there was a significant difference in mean density of living trees between dieback and

200 non-dieback plots, accounting for the total number of comparisons $(k=6)$.

201 To assess the shape of the DBH distribution, a two-parameter Weibull distribution

202 was fitted to the DBH (in cm) of living M. polymorpha trees with DBH $>2.5 \mathrm{~cm}$, both

203 for 1976 and 2003, using the function 'fitdistr' of the R package 'MASS'. Difference in

204 the skewness of the DBH distribution between dieback categories and years was tested

205 with a repeated measures ANOVA of the Weibull shape parameter, where lower values

206 of the shape parameter indicate more right-skewed distributions. In the presence of a 
207 significant interaction, we used Bonferroni-type multiple comparisons to assess which of

208 the four group means were significantly different from each other, accounting for the

209 nature (within- or between subjects) and total number of comparisons $(k=4)$. While most

210 data sets contained at least 9 trees, four dieback plots had only $3-5$ trees in 1976 . The

211 estimated shape parameters for the plots with few trees were comparable to those of the

212 other six dieback plots with at least 9 trees. Therefore, all parameters were retained and a

213 repeated measures ANOVA model could be fitted. A separate ANOVA without these

214 four values, ignoring the repeated measures in the error structure, resulted in the same

215 significant effects and pairwise comparisons (results not shown).

216 The effect of substrate age on dieback and subsequent regeneration was assessed

217 with separate simple linear regressions of substrate age and dieback index in 1976 (all

218 dieback categories), dieback index in 2003 (dieback plots only), the number of new trees

$219>5 \mathrm{~m}$ observed $1976-2003$ (log-transformed, dieback plots only) and the number of

220 living trees in 2003 (vigor classes $1-3$, dieback plots only) on substrate age (log-

221 transformed). All regression models were tested with and without no-recovery plots.

223 Results

\section{Dieback index}

225 We hypothesized that the DI (dieback index) remains low and constant in time for

226 non-dieback plots, while for dieback plots, the DI is high initially and decreases over time

227 to the level of non-dieback plots (H1). On the ten non-dieback plots, the DI fluctuated

228 perpetually around $25-30 \%$ (Fig. 4). The DI for the ten dieback plots remained high

229 until 1985 and then decreased rapidly, reaching the level of non-dieback plots by 2003 
230 (Fig. 4). In three plots ("no recovery"), the dieback index remained high at an average of 231 ca. $80 \%$. In two other plots, canopy decline occurred in the 1980's ("late dieback").

\section{Abundance of seedlings, saplings, and young trees}

We expected dieback plots to have higher densities of seedlings, saplings, and

235 young trees than non-dieback plots $(\mathbf{H 2})$. While numbers generally decreased with size

236 class, dieback plots showed higher mean abundances than non-dieback plots for almost

237 all combinations of size class and year (Fig. 5).

238 After a period of massive seedling emergence in the mid-1970s, the number of seedlings

239 strongly decreased. Seedling development on dieback plots was significantly different

240 from that on non-dieback plots (Fig. 5a); the number of seedlings was significantly

241 greater on dieback plots at all times. Here, the massive seedling emergence resulted in a

242 sapling wave (Fig. 5b-5f) that peaked in the early 1980s (1982-1985). The number of tall

243 saplings decreased since 1990 due to the recruitment of young, healthy individuals into

244 the tree layer.

245 On non-dieback plots, seedling number was highest in 1976 as well. Since then,

246 the numbers were fluctuating at a low level. Nevertheless, these fluctuations seemed to

247 reflect the high oscillations in dieback plots at a lower level. Only very few saplings grew

248 up into the new tree (NT) class in the non-dieback plots (Fig. 5g).

250 Sapling wave

251 Based on the conceptual model by Mueller-Dombois (1987), we predicted a

252 sapling wave to occur in dieback plots, but not in non-dieback plots (H3). Repeated

253 measures ANOVA of log-transformed abundance showed significant main effects for 
254 dieback category, size class, and year (Table 1). All two-way interactions were

255 significant, but not the three-way interaction. Dieback plots thus had consistently higher

256 abundances of seedlings, saplings and young trees than non-dieback plots. While the

257 magnitude of this positive difference varied between size classes or between years, it was

258 statistically significant for all size classes (Fig. 6a, left) and for all years (Fig. 6b, centre).

259 Pooled over all plots, the change in abundance through time depended on the

260 size class. The interaction plot between size class and year (Fig. 6c, right) showed a

261 systematic change in the skewness of the abundance distribution with size class. While

262 seedlings were most abundant in 1976 (L-shaped distribution), saplings of $>0.5-2 \mathrm{~m}$

263 showed a right-skewed distribution with maximum average abundances in 1982, saplings

264 of $>2-5 \mathrm{~m}$ were left-skewed with highest abundances in 1995, and young trees were

265 most abundant in 2003 (J-shaped distribution). This suggests the occurrence of a sapling

266 wave that affected numerous plots at the same time.

268 Stand structure

269 We predicted that density of vigorous M. polymorpha trees will return to the level 270 of non-dieback plots, and the shape of the DBH distribution is skewed more to the left

271 following disturbance than in non-dieback plots, and shifts back over time (H4).

Repeated measures ANOVA indicated a significant interaction effect between

273 year and dieback category on the density of living trees (vigor classes $1-3$, Table 2). In

274 non-dieback plots, the density of living trees remained constant over time with an average

275 of 820 trees per ha (Fig. 7a, left, no significant trend over time based on polynomial

276 regression). In dieback plots, the density of living trees increased markedly over time,

277 eventually levelling off (polynomial regression showed a significant positive linear trend 
278 with $p$-value $=0.008$ and significant quadratic term with $p$-value $<0.001)$. Density of

279 living trees was significantly lower in dieback plots than in non-dieback plots for $1976-$

280 1990. By 2003, mean density had returned to 815 trees per ha (Fig. 7b, right).

Vigorous trees (vigor class 1) showed the same statistically significant effect and interaction as living trees (results not shown), but in this case there was also significant fluctuation in non-dieback plots (Fig. 7a, left).

Repeated measures ANOVA of the Weibull shape parameter indicated no overall dieback effect on the shape of the DBH distribution, but a significant difference between the two years, 1976 and 2003, and a significant interaction between dieback category and time. A Weibull shape parameter value of $\mathrm{c}=3.6$ corresponds to a symmetric distribution, whereas values of $1<\mathrm{c}<3.6$ indicate a right-skewed distribution (Rennolls et al. 1985). Non-dieback plots showed no significant change in the shape of the DBH distribution over time, with generally right-skewed distributions (Fig. 8). Dieback plots

291 showed a significant shift from roughly symmetrical towards a right-skewed distribution.

292 Repeating the analysis without the shape parameter estimates that were based on less than 2939 trees did not change the nature of the ANOVA results.

\section{Stand structure and substrate age}

Regression analysis indicated that the DI in 1976 was unrelated to substrate age.

297 This was true for the full data set $\left(n=24, R^{2}=0.007\right.$, $p$-value $\left.=0.691\right)$, for all plots with

298 DI $>50 \%\left(\right.$ dieback and no-recovery plots, $\mathrm{n}=12, \mathrm{R}^{2}=0.009, \mathrm{p}$-value $\left.=0.691\right)$ and for

299 dieback plots only $\left(n=9, R^{2}=0.009\right.$, $p$-value $\left.=0.769\right)$. In the following, statistical results

300 are reported for dieback plots only. The degree of recovery by $2003\left(n=9, R^{2}=0.000\right.$,

$301 \mathrm{p}$-value $=0.988)$ and the number of living trees in $2003\left(\mathrm{n}=9, \mathrm{R}^{2}=0.042, \mathrm{p}\right.$-value $=$ 
$3020.599)$ were unrelated to substrate age, both for dieback plots $(n=9)$ and for dieback and

303 no-recovery plots $(\mathrm{n}=12)$. The only marginally significant association was found

304 between substrate age (log-transformed) and the number of new trees recruited in dieback

305 plots between $1976-2003$ (log-transformed, without no-recovery plots, $\mathrm{n}=9, \mathrm{R}^{2}=$

$3060.359, \mathrm{p}$-value $=0.088)$, where unusually low values were only observed on the youngest

307 substrates.

309 Discussion

310 Dieback Index over time

311 As predicted, the dieback index (DI) was constant over the observation period for

312 most non-dieback plots, whereas for most dieback plots, DI returned to the non-dieback

313 level by 2003. Due to growth of a new M. polymorpha cohort, the DI for dieback plots

314 decreased rapidly after 1985.

315 The two 'late-dieback' plots (22 and 23), where canopy decline did not occur until

316 the 1980s, suggest that there were different phases of dieback initiation. The progression

317 of dieback in the period from 1982 to 1985 (Akashi \& Mueller-Dombois 1995) may be

318 related to the extreme El Niño-event in 1982/1983, which caused a serious drought in

319 Hawaii's montane rain forests (Boehmer \& Niemand 2009). This interpretation is

320 supported by the marked reduction in tree vigor observed in non-dieback plots in 1982

321 and 1985 (Fig. 7a, left).

322 There were three 'no-recovery' plots $(24,37$ and 43) in which the DI remained

323 high. Additional field data (Braun-Blanquet vegetation relevés) for 1976, 1990, and 2003

324 showed high cover of Cibotium tree ferns in all three plots, though equally high

325 subcanopy cover did not prevent recovery in four of the dieback plots. On the one hand, 
326 tree fern trunks and decaying logs provide safe sites for germination of $M$. polymorpha;

327 such microhabitats typically provide for "seedling banks" in developed rain forests

328 (Mueller-Dombois et al. 1980, Medeiros et al. 1993). On the other hand, a special form

329 of competitive stress to M. polymorpha seedlings is exerted by Cibotium glaucum and the

330 less abundant Cibotium menziesii. Drake \& Pratt (2001) reported 60.3\% damaged

331 seedlings due to physical disturbance by senescing fern fronds. Plant community data

332 collected in 1976, 1990 and 2003 will need to be analysed in detail to clarify whether the

333 lack of recovery observed in the three 'non-recovery' plots can be attributed to

334 competitive interference from tree ferns ('displacement dieback'; Mueller-Dombois et

335 al.1980), or to effects of invasive alien species (Minden et al. $2010 \mathrm{a}, \mathrm{b}$ ).

\section{Population dynamics of M. polymorpha}

338 The time series analysis showed consistently higher numbers of seedlings,

339 saplings of all five height classes, and new trees, for dieback plots as compared to non-

340 dieback plots. This effect occurred in almost all combinations of size classes and years.

341 Dieback plots exhibited a nearly synchronous massive seedling emergence during the mid

3421970 s. As the mass occurrence of seedlings and the development of saplings were largely

343 restricted to dieback plots, they represent the dieback phenomenon that Mueller-Dombois

344 et al. (1980) and Jacobi et al. (1988) described as 'replacement dieback' (i.e. replacement

345 of an old M. polymorpha canopy by a new generation of the same species after dieback).

346 From a high number of seedlings, a sapling cohort developed. At the same time,

347 the number of seedlings decreased constantly. Although non-dieback plots showed a

348 considerable number of seedlings, these seedlings did not develop into saplings and

349 young trees, indicating that regeneration success was low in the absence of canopy 
350 disturbance. Some regeneration was apparent in non-dieback plots located on very moist

351 substrates (plot 25 with 54 and plot 19 with 11 new trees). Plot 25 is located on shallow,

352 discontinuous soil over poorly drained pahoehoe lava, and plot 19 on a low-lying ridge on

353 oligotrophic ash in the bog-formation terrain on Mauna Kea (Balakrishnan \& Mueller-

354 Dombois 1983). The remaining non-dieback plots produced 0 - 3 young trees over the

355 entire period of $1976-2003$.

356 After ca. 30 years, the sapling wave resulted in a new cohort of M. polymorpha

357 trees. These trees show great vigor and are expected to continue to grow up to full height,

358 with growth rates depending on the specific site conditions. By 2003, average tree density

359 in dieback plots had reached the original level of non-dieback plots estimated at 820

360 living trees per ha. In non-dieback plots, the number of living trees (vigor classes 1-3)

361 was relatively constant over time, whereas the number of vigorous trees (vigor class 1)

362 showed considerable fluctuations. A low percentage of dead or partly defoliated canopy

363 trees (vigor classes $3-5$ ) appears to be a normal characteristic of the undisturbed

364 montane M. polymorpha rain forest. Since 1976, this proportion has been fluctuating

365 around $25-30 \%$ on non-dieback plots.

366

$367 \quad$ Empirical evidence for conceptual model

368 Our four predictions (H1-H4) focused on transition of M. polymorpha individuals

369 through different size classes over time relative to Mueller-Dombois' (1987) conceptual

370 model of ohi'a dieback. The bar graphs in Fig. 9, representing our permanent plot data

371 from 1976 and 2003, allow for a direct comparison of observed size-class distributions to

372 those predicted by the model for non-dieback plots (Fig. 2A) and dieback plots (Fig. 2B).

373 The empirical data largely confirm the conceptual model. The wide-spread death of the 
374 established M. polymorpha cohort triggered large-scale synchronous regeneration, during

375 which a large number of seedlings resulted in a "sapling wave" (Fig. 9, top right). From

376 this sapling wave, a new tree cohort was recruited (Fig. 9, bottom right). Non-dieback

377 plots showed a mature cohort stand with a 'sapling gap', especially in 2003 (Fig. 9, lower 378 left).

\section{$380 \quad$ Long-term cohort dynamics}

381 Dieback seems to be a recurring natural phenomenon in the dynamics of Hawaii's

382 montane rainforests. A similar loss of $M$. polymorpha canopy was reported from the

383 lowland rainforest on the windward side of the neighbouring island of Maui in the early

384 1900's (“Maui Forest Trouble”; c.f. Lewton-Brain 1909, Lyon 1909, 1919; Holt 1983,

385 Mueller-Dombois 2006), another one even earlier from Kauai (Clarke 1875).

386 Our results show that following dieback of canopy trees in the 1970's, a new

387 cohort of Metrosideros trees was established on a wide range of substrate ages from ca.

388300 to 13,500 years. About thirty years after dieback, we found no correlation between

389 substrate age and the reduction of dieback index by 2003 , the number of new trees

390 recruited 1976 - 2003, or tree density in 2003. The lack of correlation between

391 regeneration success and substrate age (see also Jacobi et al. 1988, Akashi \& Mueller-

392 Dombois 1995) suggests that volcanic disturbance is not the main driver of present-day

393 cohort dynamics. We conclude that large-scale dieback causes a wide-spread regeneration

394 of $M$. polymorpha, leading to the maintenance of cohort dynamics even thousands of

395 years after the initial volcanic disturbance.

396 Recently, Hart (2010) presented very detailed structural data combined with novel

397 age data for a similar forest on Mauna Kea. In this forest, he found three different cohorts 
398 of M. polymorpha separated by $200-250$ years. Although gap dynamics is, as far as we

399 know today, not a relevant process in our study area, forest regeneration between

400 episodes of dieback may be driven by canopy gap dynamics in places (Kellner et al.

401 2011). More research is needed applying novel tree dating methods to our non-dieback

402 permanent plots to determine whether the co-occurrence of multiple cohorts within stands

403 is a general phenomenon or linked to the specific history of the stand studied by Hart

404 (2010).

405

406 Acknowledgements

407 This research was funded by the German Research Foundation (DFG) grant BO

4081768 to H. J. B., the National Science Foundation grant DEB-7910993 to D. M.-D., the

409 U.S. Geological Survey's Ecosystems Research Program, and a Discovery Grant to H. H.

410 W. by the Natural Sciences and Engineering Research Council of Canada. Permission to

411 use the study sites was given by the Hawai'i Volcanoes National Park, U.S. Park Service,

412 and the Hawai'i Division of Forestry and Wildlife. We thank Laurel Duquette for fruitful

413 discussions, Patrick Hart, Jeff Hatfield, Catherine Reynolds and two anonymous

414 reviewers for helpful comments on the manuscript, and the many colleagues that

415 contributed to the accomplishment of the challenging field work over 30 years. Mention

416 of specific software or products by name does not constitute an endorsement by the U.S.

417 Geological Survey or other institutions involved with this research. 


\section{References}

422 Akashi Y. \& Mueller-Dombois, D. 1995. A landscape perspective of the Hawaiian 423 rainforest dieback. Journal of Vegetation Science 6: 449-464.

424 Allen, C. D. 2009. Climate-induced forest dieback: an escalating global phenomenon? $425 \quad$ Unasylva 231/232, 60: 43-49.

426 Allen, C. D., Macalady, A. K., Chenchouni, H., Bachelet, D., McDowell, N., Vennetier, 427 M., Kitzberger, T., Rigling, A., Breshears, D. D., Hogg, E.H., Gonzalez, P., Fensham, 428 R., Zhang, Z., Castro, J., Demidova, N., Lim, J.-H., Allard, G., Running, S. W., 429 Semerci, A. \& Cobb, N. 2010. A global overview of drought and heat-induced tree 430 mortality reveals emerging climate change risks for forests. Forest Ecology and $431 \quad$ Management 259 (4): 660-684.

432 Atkinson, I. A. E. 1970. Successional trends in the coastal and lowland forest of Mauna 433 Loa and Kilauea Volcanoes, Hawaii. Pacific Science 24: 387-400.

434 Auclair, A. N. D. 1993: Extreme climatic fluctuations as a cause of forest dieback in the 435 Pacific rim. Water Air and Soil Pollution 66: 207-229.

436 Aynekulu, E., Denich, M., Tsegaye, D., Aerts, R., Neuwirth, B. \& Boehmer, H. J. 2011. 437 Dieback affects forest structure in a dry Afromontane forest in northern Ethiopia. 438 Journal of Arid Environments 75: 499-503.

439 Balakrishnan, N. \& Mueller-Dombois, D. 1983. Nutrient Studies in Relation to Habitat 440 Types and Canopy Dieback in the Montane Rain Forest Ecosystem, Island of Hawai i. $441 \quad$ Pacific Science 37 (4): 339-359.

442 Boehmer, H. J. 2005. Dynamik und Invasibilitaet des montanen Regenwaldes auf der 443 Insel Hawaii (Dynamics and Invasibility of Hawaii's Montane Rainforest). Habilitation 
$445 \quad$ Management.

446 Boehmer, H. J. 2011. Vulnerability of tropical montane rain forest ecosystems due to

447 climate change. In: Brauch, H. G., Oswald Spring, Ú., Mesjasz, C., Grin, J., Kameri-

448 Mbote, P., Chourou, B., Dunay, P. \& Birkmann, J. (eds.) Coping with Global Environmental Change, Disasters and Security - Threats, Challenges, Vulnerabilities and Risks. pp. 789-802. Springer, Berlin - Heidelberg - New York. Establish a Typology and Zonal System. Plant Research and Development 45: 74-88. 453 Boehmer, H. J. \& Niemand, C. 2009. Die neue Vegetationsdynamik pazifischer Wälder 454 (The new dynamics of Pacific forests). Wie Klimaextreme und biologische Invasionen 455 Inselökosysteme verändern (How climatic anomalies and biological invasions change 456 island ecosystems). Geographische Rundschau 61(4): 32-37.

457 Burgan, R. E. \& Nelson, R.E. 1972. Decline of Ohia lehua forests in Hawaii. US

458 Department of Agriculture, Forest Service, General Technical Report PSW-3.

459 Ciesla, W. M. \& Donaubauer, E. 1994. Decline and dieback of trees and forests: A global $460 \quad$ view. FAO Forestry Paper 120: 1-90.

461 Clarke, F. L. 1875. Decadence of Hawaiian Forest. All about Hawaii 1: 19-20.

462 Drake, D. \& Pratt, L. 2001. Seedling mortality in Hawaiian Rain forest: The role of small 463 scale physical disturbance. Biotropica 33(2): $319-323$.

464 Gerrish, G. C. 1990. Relating Carbon Allocation Patterns to Tree Senescence in 465 Metrosideros Forests. Ecology 71(3): 1176-1184.

466 Gerrish, G. C., Mueller-Dombois, D. \& Bridges, K.W. 1988. Nutrient limitation and 467 Metrosideros dieback in Hawaii. Ecology 69: 723-727. 
468 Gerrish, G. C. \& Mueller-Dombois, D. 1999. Measuring Stem Growth Rates for

469 Determining Age and Cohort Analysis of a Tropical Evergreen Tree. Pacific Science

$470 \quad 53(4): 418-429$.

471 Hart, P. J. 2010. Tree growth and age in an ancient Hawaiian wet forest: vegetation

472 dynamics at two spatial scales. Journal of Tropical Ecology 25:1-11.

473 Hodges, C. S., Adee, K. T., Stein, J. D., Wood, H. B. \& Doty, R.D. 1986. Decline of Ohia

474 (Metrosideros polymorpha) in Hawaii: a review. United States Department of

475 Agriculture, Forest Service, Pacific Southwest Forest and Range Experiment Station.

476 General Technical Report PSW-86.

477 Holloway, J. D. 1977. The Lepidoptera of Norfolk Island, their biogeography and

478 ecology. Dr. W. Junck B.V. The Hague, Netherlands.

479 Holt, R. A. 1983. The Maui forest trouble: a literature review and proposal for research.

480 Hawaii Botanical Science Paper No. 42. University of Hawaii, Honolulu.

481 Howell, D. C. 2010. Fundamental Statistics for the Behavioral Sciences. $7^{\text {th }}$ Ed.,

482 Wadsworth. Belmont, U.S.A.

483 Itow, S. \& Mueller-Dombois, D. 1988. Population structure, stand-level dieback and

484 recovery of Scalesia pedunculata forest in the Galapagos Islands. Ecological Research

$485 \quad 3: 333-339$.

486 Jacobi, J. D. 1983. Metrosideros Dieback in Hawai'i: A Comparison of Adjacent Dieback

487 and Non-Dieback Rain Forest Stands. New Zealand Journal of Ecology 6: 79-97.

488 Jacobi, J. D. 1993. Distribution and dynamics of Metrosideros dieback on the island of

489 Hawaii: Implications for management programs. In: Huettl, R. F. \& D. Mueller-

490 Dombois (eds.), Forest Decline in the Atlantic and Pacific Regions, 236-242.

$491 \quad$ Heidelberg. 
492 Jacobi, J. D., Gerrish, G. C., Mueller-Dombois, D. 1983. 'Ohi’a Dieback in Hawaìi:

493 Vegetation Changes in Permanent Plots. Pacific Science 37 (4): 327-337.

494 Jacobi, J. D., Gerrish, G. C., Mueller-Dombois, D. \& Whiteaker, L. 1988. Stand-level

495 Dieback and Metrosideros Regeneration in the Montane Rain Forest of Hawaii.

$496 \quad$ GeoJournal 17 (2): 193-200.

497 Jane, G. T. \& Green, G. M. J. 1983. Vegetation Mortality in the Kaimai Ranges, North

498 Island, New Zealand. Pacific Science 37: 385-389.

499 Juvik, S. P. \& Juvik, J. O. 1998. Atlas of Hawai'i. $3^{\text {rd }}$ Edition, Honolulu.

500 Kellner, J. R., Asner, G. P., Vitousek, P. M., Tweiten, M. A,, Hotchkiss, S. Chadwick, O.

501 A. (2011): Dependence of Forest Structure and Dynamics on Substrate Age and

502 Ecosystem Development. Ecosystems 14: 1156-1167.

503 Kliejunas, J. T. \& Ko, W. H. 1973. Root rot of ohia (Metrosideros collina, ssp.

504 polymorpha) caused by Phytophthora cinnamomi. Plant Disease Reporter 57: $383-$

505384.

506 Kliejunas J. T. \& Ko, W. H. 1974. Deficiency of inorganic nutrients as a contributing

507 factor to ohia decline. Phytopathology 64: 891-896.

508 Kohyama, T. 1988. Etiology of "Shimagare” Dieback and Regeneration in Subalpine

$509 \quad$ Abies Forests of Japan. GeoJournal 17: 201-208.

510 Lawesson, J. E. 1988. Stand-level dieback and regeneration of forests in the Galapagos

$511 \quad$ Islands. Vegetatio 77: 87-93.

512 Lewis, S. L., Brando, P. M., Phillips, O. L., van der Heijden, G. M. F. \& Nepstad, D.

513 2011. The 2010 Amazon Drought. Science 331: 554.

514 Lewton-Brain, L. 1909. The Maui forest trouble. Hawaiian Planters'Record 1: 92-95.

515 Lyon, H. L. 1909. The forest disease on Maui. Hawaiian Planters 'Record 1: 151-159. 
516 Lyon, H. L. 1919. Some observations on the forest problems of Hawai'i. Hawaiian

517 Planters'Record 21: 289-300-159.

518 Manion, P. D. 1981. Tree disease concepts. Englewood Cliffs, N. J..

519 Medeiros. A. C., Loope, L. L., Anderson, S. J. 1993. Differential colonization by

520 epiphytes on native (Cibotium spp.) and alien (Cyathea cooperi) tree ferns in a

$521 \quad$ Hawaiian rain forest. Selbyana 14: 71-74.

522 Minden, V., Henneberg, K. J., Porembski, S. \& Boehmer, H. J. 2010a. Invasion and

523 management of alien Hedychium gardnerianum (kahili ginger, Zingiberaceae) alter

524 plant species composition of a montane rainforest on the island of Hawai'i. Plant 525 Ecology 206: 321-333.

526 Minden, V., Jacobi, J. D., Porembski, S. \& Boehmer, H. J. 2010b. Effects of invasive

527 alien kahili ginger (Hedychium gardnerianum) on native plant species regeneration in a

$528 \quad$ Hawaiian rainforest. Applied Vegetation Science 13 (1): 5-14.

529 Mueller-Dombois, D. 1980. The 'Ohi`a Dieback Phenomenon in the Hawaiian Rain

530 Forest. Pages 153-161 In: The Recovery Process in Damaged Ecosystems. John

531 Cairns, Jr., ed. Ann Arbor Science Publishers Inc.

532 Mueller-Dombois, D. 1987. Natural Dieback in Forests. BioScience 37 (8): 575-583.

533 Mueller-Dombois, D. 1993a. Forest Decline in the Hawaiian Islands: A Brief Summary.

534 Pages 229-235 In: Forest Decline in the Atlantic and Pacific Regions. R. F. Huettl and

535 D. Mueller-Dombois, eds. Springer-Verlag, Berlin/Heidelberg/New York

536 Mueller-Dombois, D. 1993b. Biotic Impoverishment and Climate Change: Global Causes

537 of Forest Decline? Pages 338-348 In: Forest Decline in the Atlantic and Pacific

538 Regions. R.F. Huettl \& D. Mueller-Dombois, eds., Springer-Verlag,

539 Berlin/Heidelberg/NY. 
540 Mueller-Dombois, D. 2006. Long-term rain forest succession and landscape change in

541 Hawai'i: The `Maui Forest Trouble`revisited. Journal of Vegetation Science 17: 685-

$542 \quad 692$.

543 Mueller-Dombois, D., Jacobi, J. D., Cooray, R. G. \& Balakrishnan, N. 1980. 'Ohi `a Rain

544 Forest Study: Ecological Investigations of the 'Ohi a Dieback Problem in Hawaii.

545 Hawaii Agricultural Experiment Station 183, Miscelaneous Publication 183: 1-64.

546 Mueller-Dombois, D. \& Fosberg, F.R. 1998. Vegetation of the Tropical Pacific Islands.

547 Springer-Verlag, New York/Berlin/Heidelberg.

548 Ogden, J. 1988. Forest Dynamics and Stand-level Dieback in New Zealand's Nothofagus

$549 \quad$ Foretsts. Geo Journal 17: 225-230.

550 Ogden, J. Lusk,Ch. H., \& Steel, M.G. 1993. Pages 261-274 In: Forest Decline in the

$551 \quad$ Atlantic and Pacific Regions. F.R. Huettl \& D. Mueller-Dombois, eds., Springer-

$552 \quad$ Verlag. Berlin, Heidelberg, NY.

553 Papp, R.P., Kliejunas, J. T., Smith, R. J. \& Scharpf, R. F. 1979. Association of

$554 \quad$ Plagithmysus bilineatus and Phytophthora cinnamoni with the decline of Ohia lehua

555 forests on the island of Hawaii. Forest Science 25: 187-196.

556 Petteys, E. Q. P., Burgan R. E \& Nelson, R.E. 1975. Ohia forest decline: Its spread and

557 severity in Hawaii. PSW - 105, USDA Forest Service.

558 Pickard, J. 1983. Vegetation of Lord Howe Island. Cunninghamia 1:133-266.

559 Podger, F. D. 1981. Definition and diagnosis of diebacks. In Eucalypt Dieback in Forests

560 and Woodlands, ed. K.M. Old, G. A. Kile, C. P. Ohmart, 1-8. Melbourne.

561 Rennolls, K., Geary, D.N. \& Rollinson, T.J.D. 1985. Characterising Diameter

562 Distributions by the use of the Weibull Distribution. Forestry 58, No 11. 
563 Stewart, G.H. \& Veblen, T.T. 1983. Forest Instability and Canopy Tree Mortality in

$564 \quad$ Westland, New Zealand. Pacific Science 37: 427-431.

565 Stewart, G. H. 1989. Ecological considerations of dieback in New Zealand's indigenous

566 forests. New Zealand Journal of Forestry 19: 243-249.

567 Trusdell, F. A., Wolfe, E. W. \& Morris, J. 2006. Digital Database of the Geologic Map of

568 the Island of Hawai‘i. U.S. Geological Survey Data Series 144, version 1.0. URL:

569 http://pubs.usgs.gov/ds/2005/144/

570 Vogl, R.J. 1969. The role of fire in the evolution of the Hawaiian flora and vegetation.

$571 \quad$ Proceedings Annual Tall Timbers Fire Ecology Conference April 10-11,1969:5-60.

572 Wagner, W. L., Herbst, D. R. \& Sohmer, S. H. 1999. Manual of the Flowering Plants of

573 Hawai`i. University of Hawaii Press, Honolulu.

574 Wardle, J.A. \& Allen, R.B. 1983. Dieback in New Zealand Nothofagus Forests. Pacific

$575 \quad$ Science: $397-404$.

576 White, T. C. R. 1986. Weather, Eucalyptus Dieback in New England, and a General

577 Hypothesis of the Cause of Dieback. Pacific Science 40: 58-78.

578

579

580

581

582 Appendix S1: Substrate age and stand composition of permanent plots in 1976

583 and 2003. 
584 Table 1: Repeated measures ANOVA of the effect of dieback category, size

585 class, and year on log-transformed sapling abundance. The final model

586 includes main effects and two-way interactions only, as the three-way

587 interaction was not statistically significant.

\begin{tabular}{|l|l|r|r|r|r|r|}
\hline $\begin{array}{l}\text { Error } \\
\text { component }\end{array}$ & Term & Df & $\begin{array}{c}\text { Sum } \\
\text { Sq }\end{array}$ & $\begin{array}{c}\text { Mean } \\
\text { Sq }\end{array}$ & F value & p-value \\
\hline Plot & Dieback & 1 & 293.6 & 293.62 & 25.50 & $<0.001$ \\
\hline & Residuals & 18 & 207.3 & 11.51 & & \\
\hline Within & Stage & 6 & 545.9 & 90.99 & 111.30 & $<0.001$ \\
\hline & Time & 5 & 41.5 & 8.31 & 10.16 & $<0.001$ \\
\hline & Dieback:Stage & 6 & 60.1 & 10.02 & 12.25 & $<0.001$ \\
\hline & Dieback:Time & 5 & 10.3 & 2.06 & 2.51 & 0.029 \\
\hline & Stage:Time & 30 & 127.1 & 4.24 & 5.18 & $<0.001$ \\
\hline & Residuals & 768 & 627.8 & 0.82 & & \\
\hline
\end{tabular}

588

589 
Boehmer et al.: Rebuilding after collapse Table 2: Repeated measures ANOVA of the effect of year and dieback

591 category on the density of living trees (square-root transformed).

\begin{tabular}{|l|l|r|r|r|r|r|}
\hline $\begin{array}{l}\text { Error } \\
\text { component }\end{array}$ & Term & Df & Sum Sq & $\begin{array}{c}\text { Mean } \\
\text { Sq }\end{array}$ & F value & p-value \\
\hline Plot & Dieback & 1 & 122.6 & 122.62 & 15.72 & 0.0009 \\
\hline & Residuals & 18 & 140.4 & 7.80 & & \\
\hline Within & Year & 5 & 36.0 & 7.21 & 5.59 & 0.0002 \\
\hline & Year:Dieback & 5 & 31.5 & 6.29 & 4.88 & 0.0005 \\
\hline & Residuals & 90 & 116.0 & 1.29 & & \\
\hline
\end{tabular}

592

593 
Boehmer et al.: Rebuilding after collapse

595 category on Weibull shape parameter as an indicator for the skewness of DBH

596 distribution.

\begin{tabular}{|l|l|r|r|r|r|r|}
\hline $\begin{array}{l}\text { Error } \\
\text { component }\end{array}$ & Term & Df & Sum Sq & $\begin{array}{c}\text { Mean } \\
\text { Sq }\end{array}$ & F value & p-value \\
\hline Plot & Dieback & 1 & 0.244 & 0.244 & 0.32 & 0.5773 \\
\hline & Residuals & 18 & 13.607 & 0.756 & & \\
\hline Within & Year & 1 & 6.055 & 6.055 & 19.38 & 0.0003 \\
\hline & Year:Dieback & 1 & 4.854 & 4.854 & 15.53 & 0.0010 \\
\hline & Residuals & 18 & 5.625 & 0.313 & & \\
\hline
\end{tabular}

597

598 
Boehmer et al.: Rebuilding after collapse

Fig. 1:

600

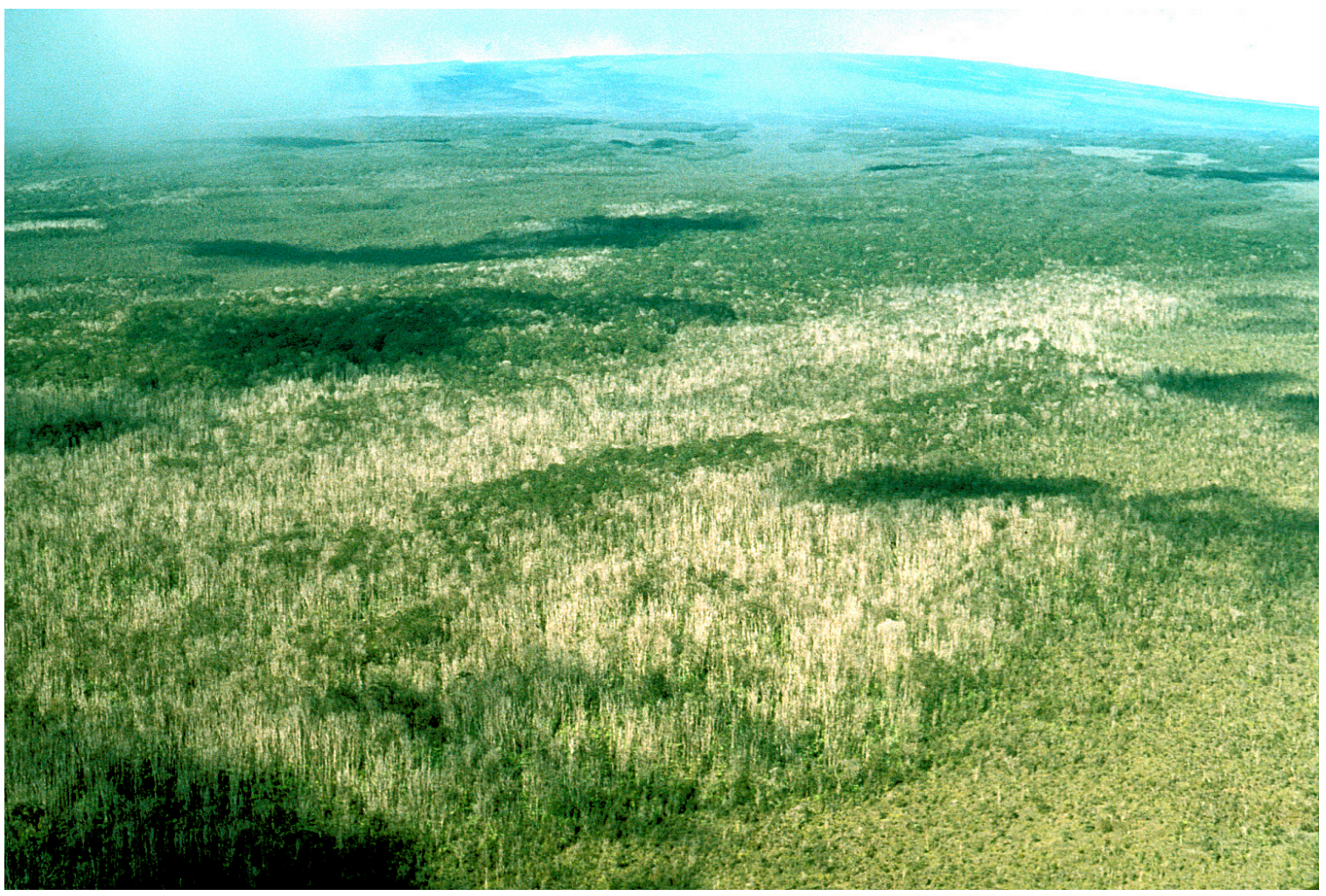

601

602 Fig. 1: A 1972 aerial photograph of Metrosideros polymorpha dieback in the

603 montane rain forest on the eastern flanks of Mauna Kea and Mauna Loa, island of

604 Hawaii. (Photograph by Dieter Mueller-Dombois)

605 
Boehmer et al.: Rebuilding after collapse

606

Fig. 2:

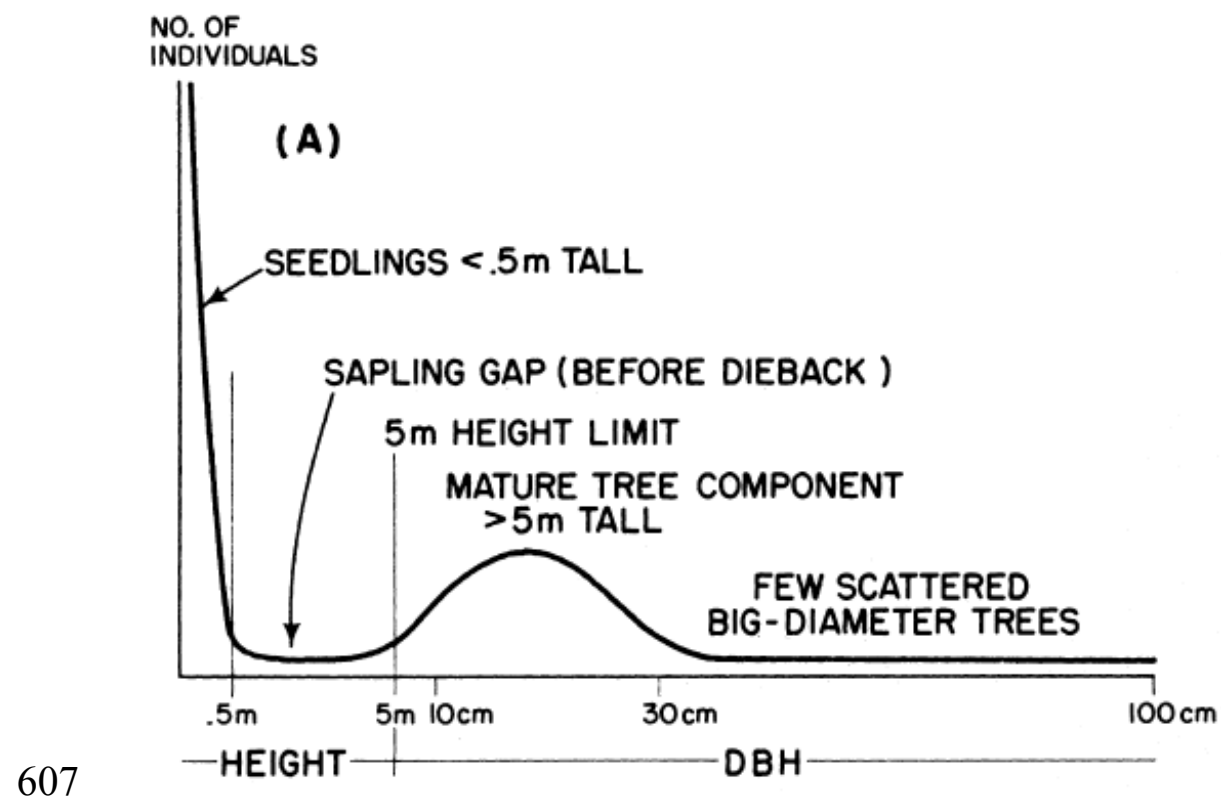

608

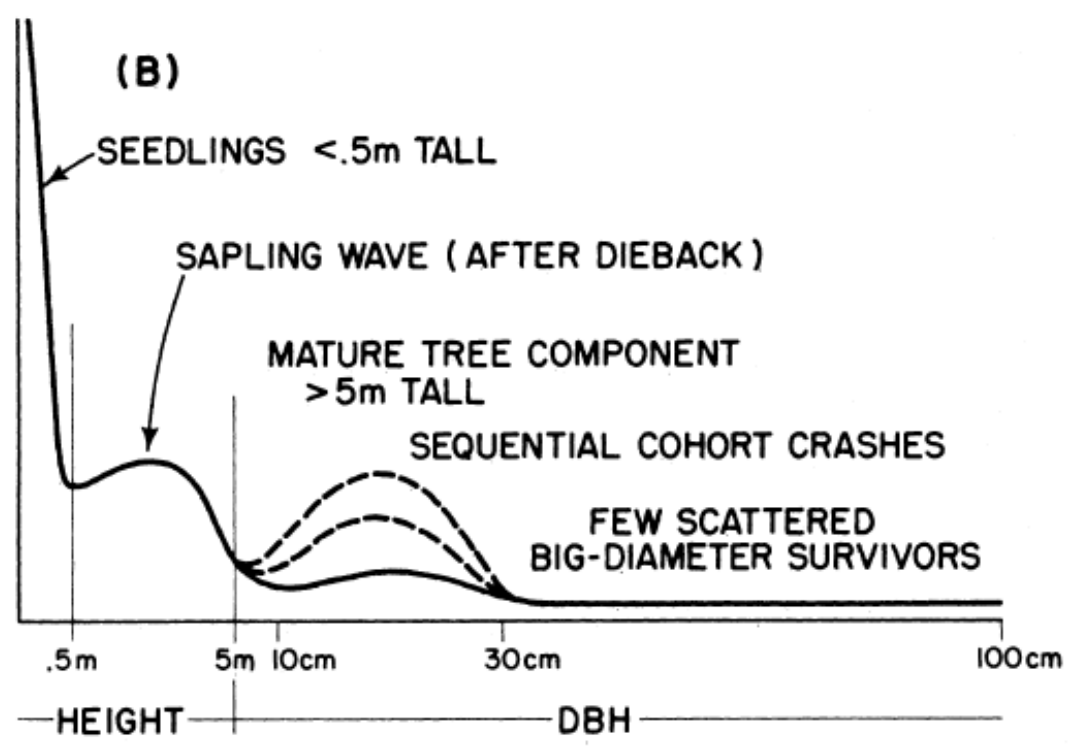

610

611 Fig. 2: Conceptual model of M. polymorpha stand structure before and after

612 dieback (Mueller-Dombois 1987). Reprinted with permission from BioScience 37, by

613 American Institute of Biological Science.

614 
Boehmer et al.: Rebuilding after collapse

\section{Fig. 3:}

616

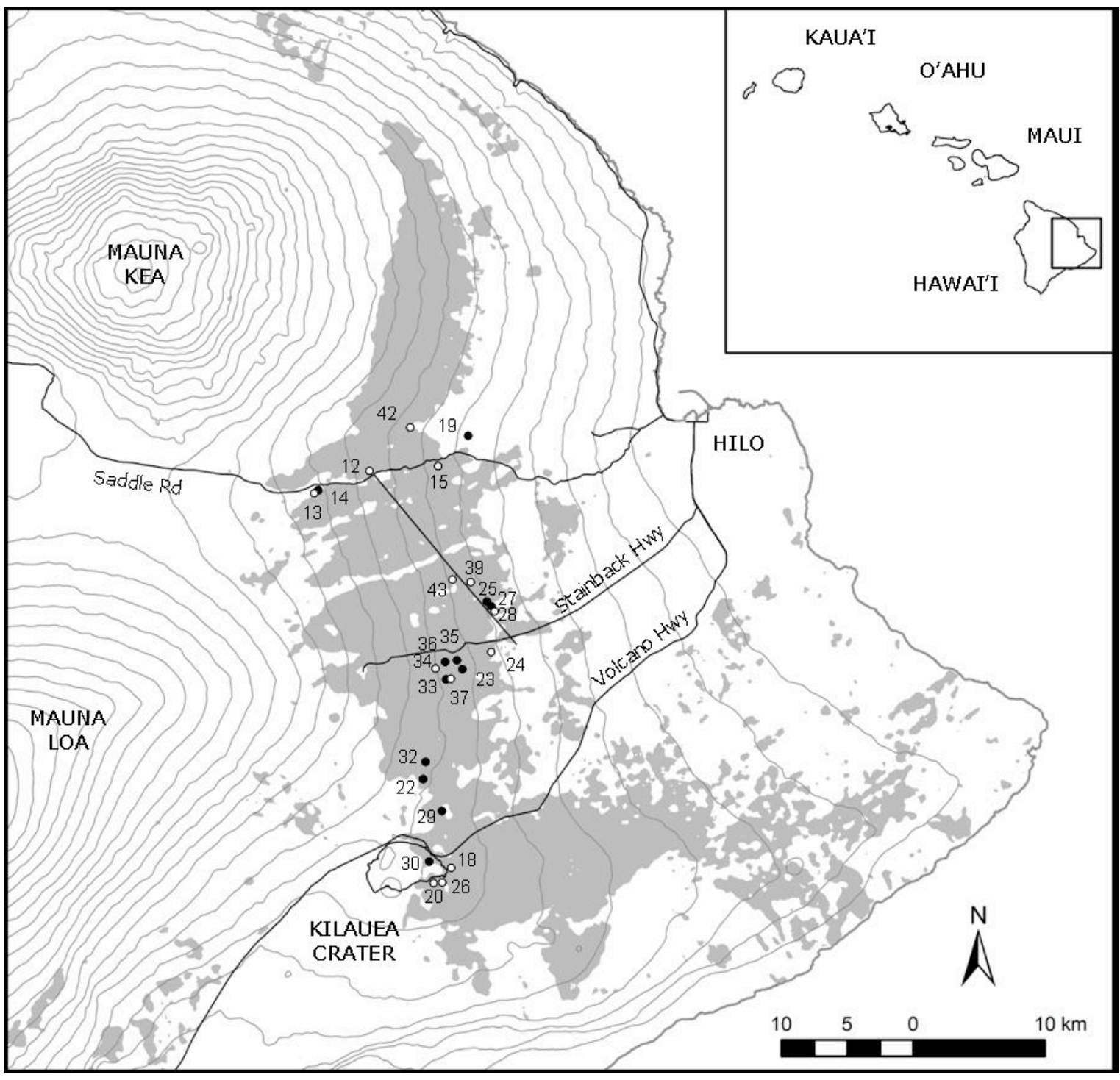

618 Fig. 3: Study area on the island of Hawaii. Grey colour indicates M. polymorpha-

619 dominated forests. Numbers indicate plot numbers of dieback (white) and non-dieback 620 plots (black). 


\section{$621 \quad$ Fig. 4:}
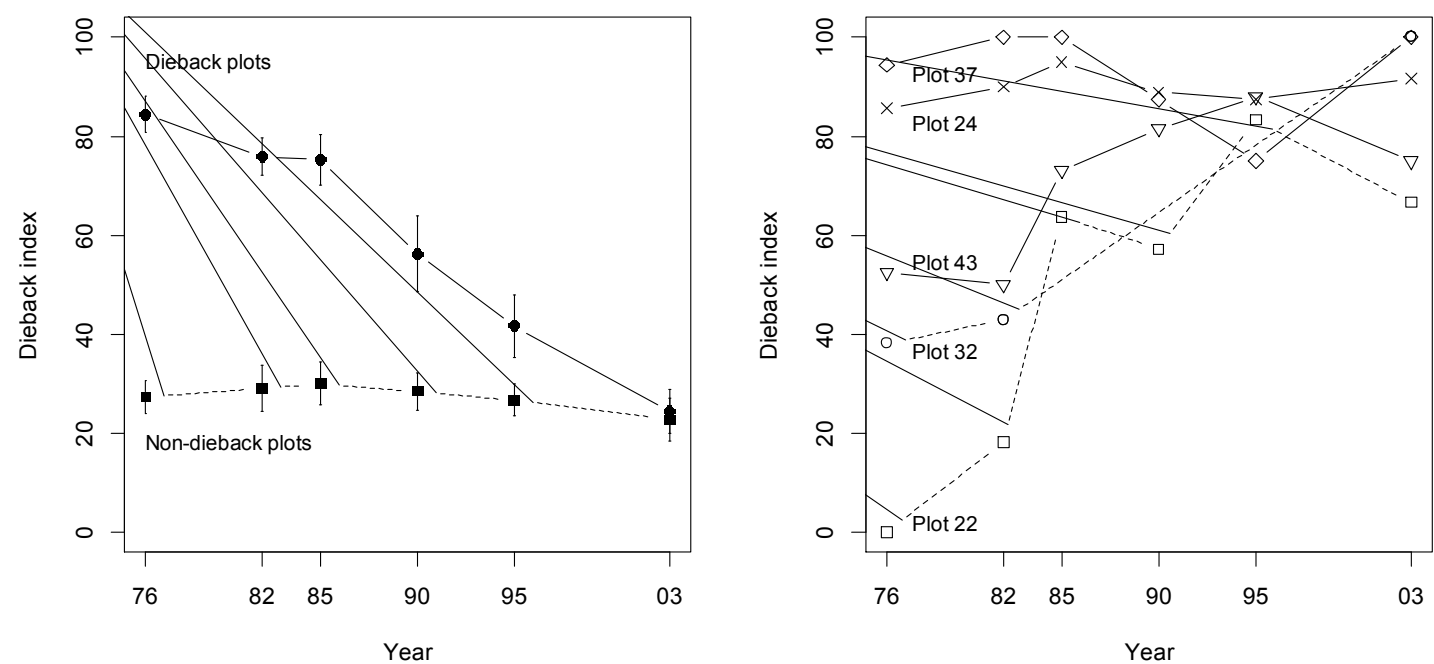

625 or dying canopy trees per plot, vigor classes 3 - 5) for non-dieback (squares, dashed line,

$626 \mathrm{n}=10$ ) and dieback plots (circles, solid line, $\mathrm{n}=10$ ). Right: DI for three no-recovery

627 plots (solid lines) and two late dieback plots (dashed lines; Plot 32 with missing values

628 for $1985-1995)$. 
Boehmer et al.: Rebuilding after collapse

631 Fig. 5:

632
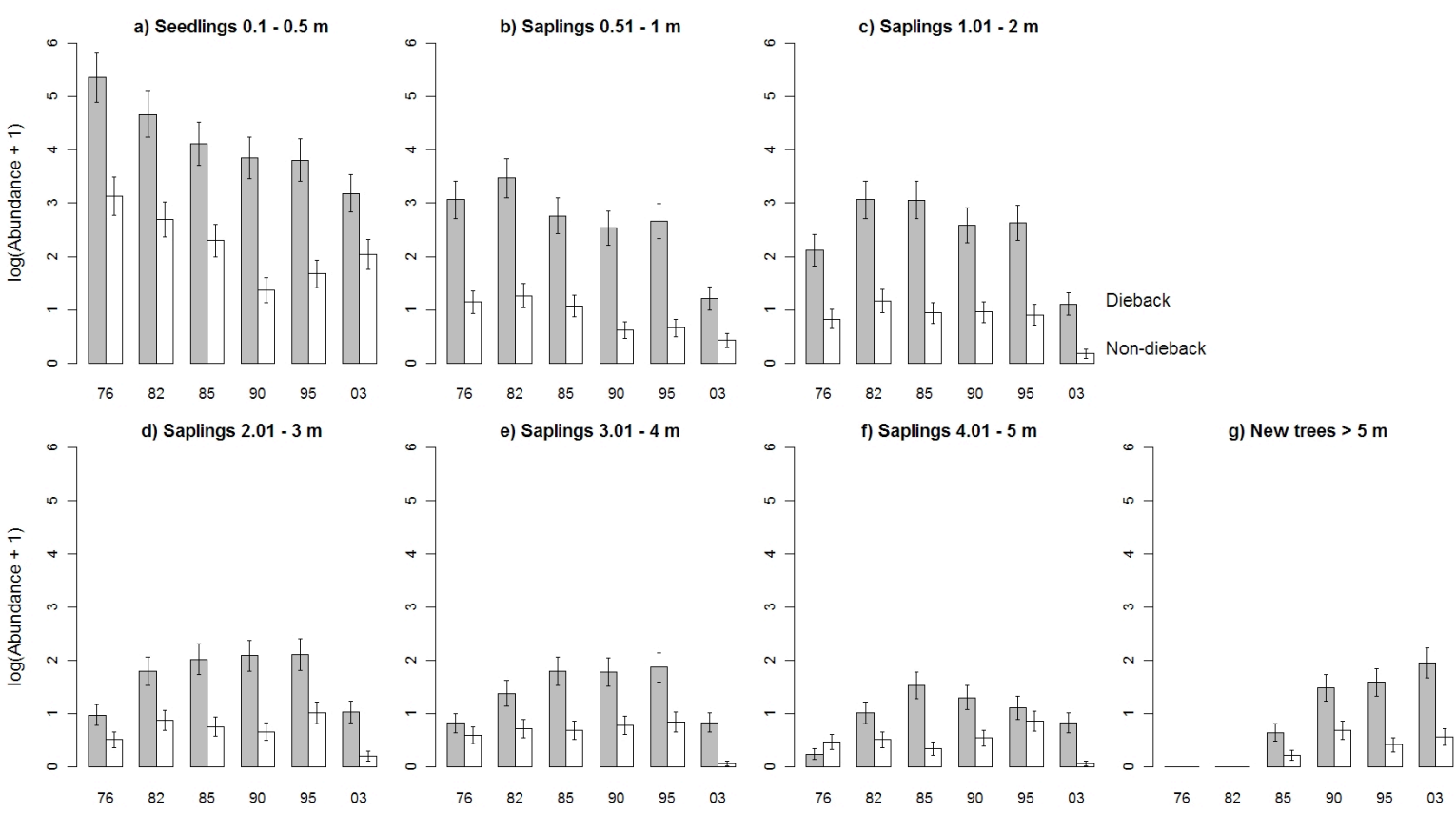

Fig. 5: Regeneration of Metrosideros polymorpha from seedlings to new trees in

638 seven height classes. Barplots showing the mean $\pm \mathrm{SE}$ of log-transformed counts of

639 seedlings, saplings and new trees for each time step, separately for non-dieback (white, $\mathrm{n}$

$640=10)$ and dieback plots (grey, $\mathrm{n}=10$ ).

641

642

643

644 


\section{Fig. 6:}

646

647
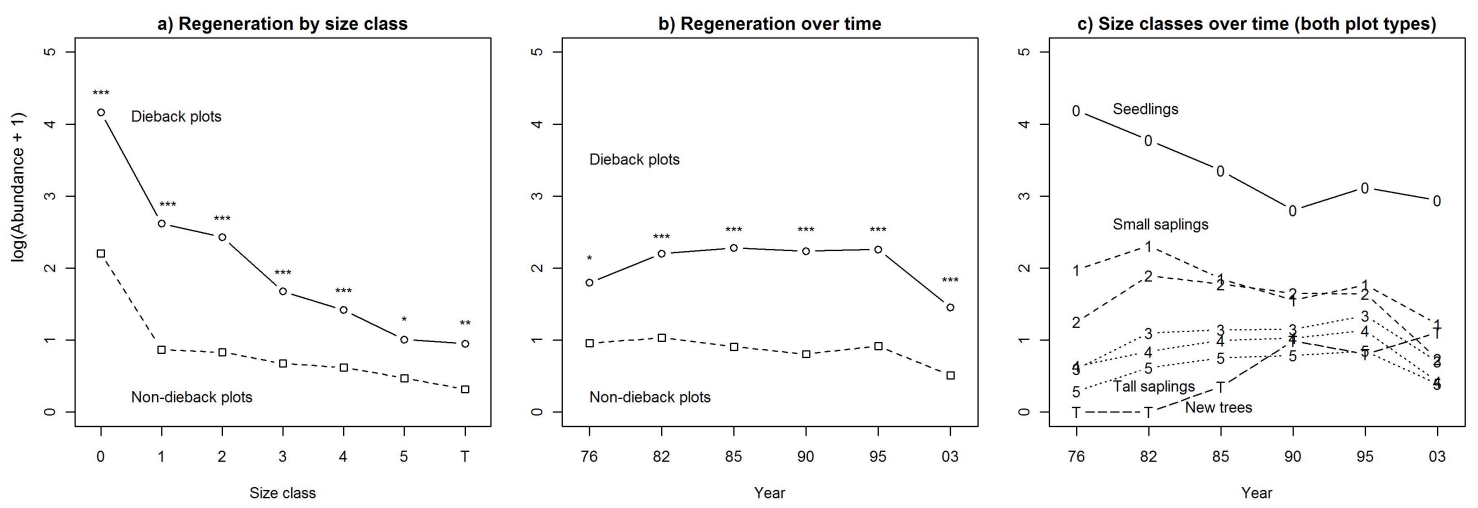

Fig. 6: Interaction plots of abundance as a function of size. Abundance (log-

651 transformed) is plotted for each size class (0: seedlings $0.1-0.5 \mathrm{~m}, 1-5$ : sapling height

652 classes $1-5, \mathrm{~T}$ : young trees $>5 \mathrm{~m}$ ) and dieback category (a; circles: dieback plots, $\mathrm{n}=$

653 10, squares: non-dieback plots, $\mathrm{n}=10$ ), time step and dieback category (b), and time step

654 and size class, pooled over both plot types (c; 0: seedlings $0.1-0.5 \mathrm{~m}, 1-5$ : sapling

655 height classes $1-5, \mathrm{~T}$ : young trees $>5 \mathrm{~m}$; line types group size classes with similar

656 changes over time). Star notation indicates significance of one-sided t-tests comparing

657 dieback and non-dieback plots for each size class, using Bonferroni correction for the

658 total number of tests $(*: \mathrm{p}<0.05 / 13, * *: \mathrm{p}<0.01 / 13, * * *: \mathrm{p}<0.001 / 13)$.

659

660 

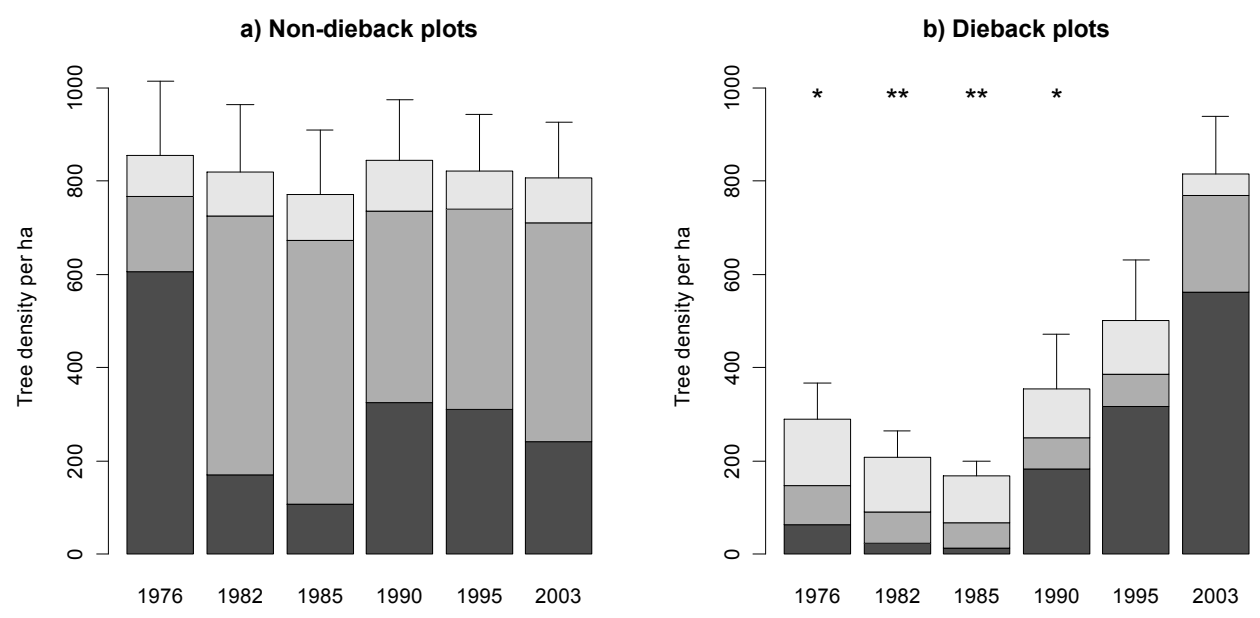

663

664

665

Fig. 7: Mean density of living trees over time. Each stacked barplot shows the

666 mean density of trees of vigor classes 1 (dark grey), 2 (medium grey) and 3 (light grey)

667 per ha and per observation period for the ten non-dieback plots (a) and the ten dieback

668 plots (b). Error bars denote mean $+\mathrm{SE}$ for the number of living trees (vigor classes $1-$

669 3). Asterisks indicate years with a signficant difference between the mean density of

670 living trees in non-dieback and dieback plots based on Bonferroni tests of $k=6$ pairwise

671 comparisons $(*: \mathrm{p}<0.05 / 6, * *: \mathrm{p}<0.01 / 6)$.

672 


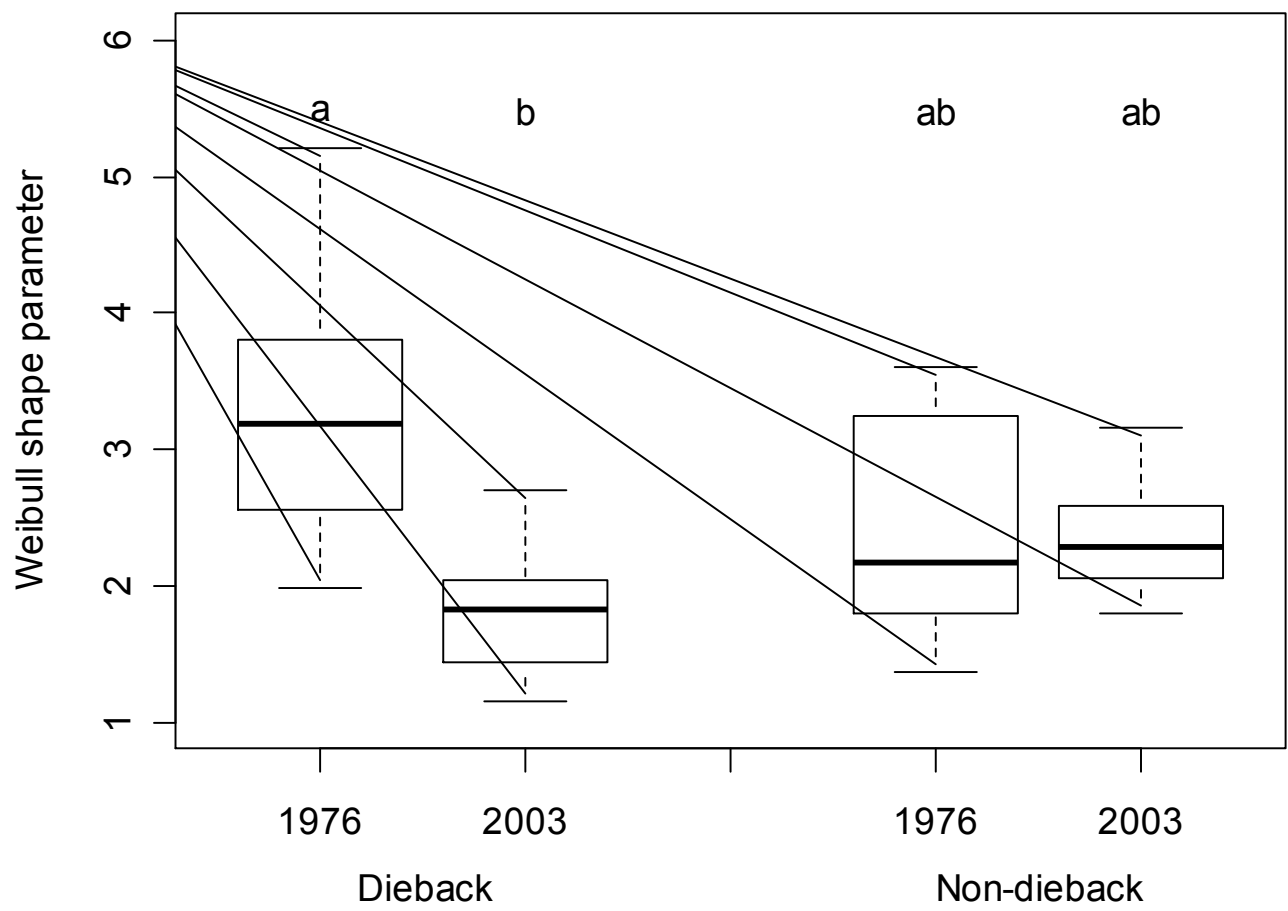

678 of a 2-parameter Weibull distribution fitted to the DBH data of all living M. polymorpha

679 trees (vigor classes $1-3$ ) with $\mathrm{DBH}>2.5 \mathrm{~cm}$, separately for dieback (left, $\mathrm{n}=10)$ and

680 non-dieback plots (right, $\mathrm{n}=10$ ) and the two years 1976 and 2003. Letters indicate

681 significance of pairwise differences (Tukey HSD, $\alpha=0.05$ ).

682

683 
Fig. 9:

685

686
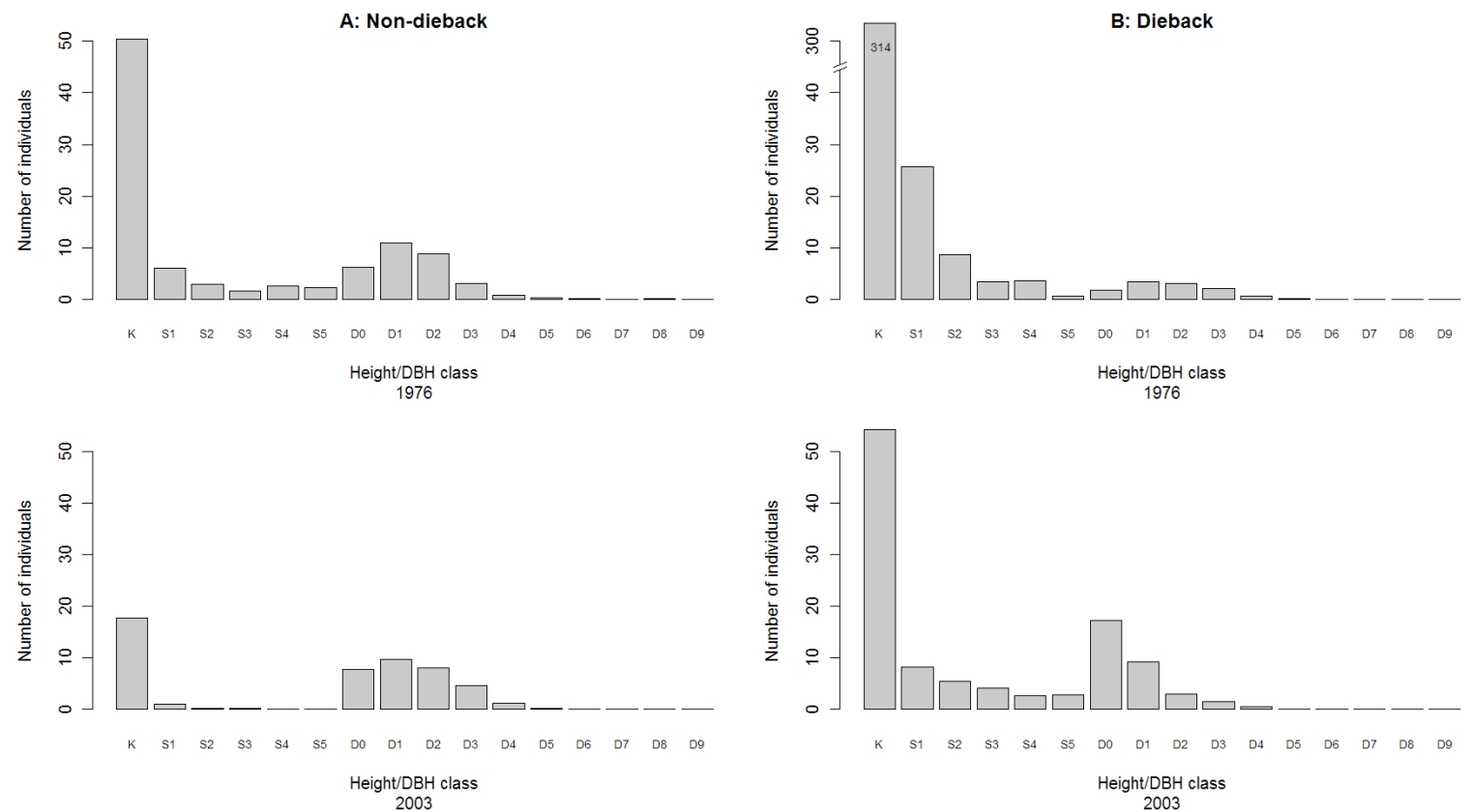

Fig. 9: M. polymorpha stand structure based on empirical data. Empirical

691 population structure of $M$. polymorpha in non-dieback (left, A) and dieback stands (right,

692 B) in 1976 (top) and 2003 (bottom) to be compared to the conceptual model in Fig. 2.

693 Each bar shows the number of individuals of seedlings $(\mathrm{K})$, each of five saplings height

694 classes (S1 - S5), and different DBH classes (D0 - D9), where D0 contains trees with a

$695 \mathrm{DBH}$ of $2.5 \mathrm{~cm}$ up to $<10 \mathrm{~cm}$, D1 of $10 \mathrm{~cm}$ up to $<20 \mathrm{~cm}$, etc. Note that the $\mathrm{y}$-axis is

696 interrupted for dieback plots in 1976 to accommodate the extremely high number of

697 seedlings. 